\title{
Evaluation of Alfalfa Plants Growth Irrigated with Arsenic Contaminated Water
}

\author{
Sukru Aslan, PhD \\ Cumhuriyet University, \\ Environmental Engineering Department, Sivas, Turkey \\ Mustafa Ozturk, PhD \\ Ahmet Demirbas, PhD \\ Tolga Karakoy, PhD \\ Cumhuriyet University, Department of Organic Agriculture, Sivas \\ Vocational School of Higher Education, Sivas, Turkey
}

Doi: 10.19044/esj.2018.c5p10 ～URL:http://dx.doi.org/10.19044/esj.2018.c5p10

\begin{abstract}
The natural and anthropogenic process cause arsenic contamination of waters and creates serious environmental problems throughout the world. Due to the alfalfa is an important crop in diverse farming systems, it has been grown almost 33\% of Turkey's cropland. In this experimental study, effect of As on the alfalfa plant growth and As accumulation in the shoot of the alfalfa was determined.

The accumulation of As in shoots as well as growth of alfalfa at various As contaminated water was evaluated. Alfalfa plants were grown in a greenhouse on a soil amended with different concentrations of As (control, $0.5-1.0-1.5-2.0-2.5-3.0-4.0-6.0-8.0 \mathrm{mg} / \mathrm{L}$ ). In this study, data of two harvest samples were presented. Experimental results indicated that the irrigation with As-contaminated water of alfalfa cause dry weight increase compared to control pots. As accumulation in the shoots of alfalfa plant increase with increasing As concentrations in the irrigation waters. As accumulation in the shoots at the $2^{\text {nd }}$ harvest samples were higher than the $1^{\text {st }}$ samples. However, As accumulation differences between the $1^{\text {st }}$ and $2^{\text {nd }}$ samples decreased when the As concentrations in the irrigation water was higher than $4 \mathrm{mg} / \mathrm{L}$.
\end{abstract}

Keywords: Alfalfa, Arsenic, Irrigation water 


\section{Introduction}

Arsenic (As) is a naturally occurring element in the environment. Since ancient times, metalloid As has been known as a toxic element and widely distribute in the worlds (Dahal et al., 2008). As occurs in both inorganic and organic forms and inorganic As forms are about 100 times more toxic than organic forms (Jain ve Ali 2000). Inorganic forms of As occur in five oxidation states out of which the less toxic arsenates $(+5)$ and more toxic arsenites (+3).

As contamination of groundwater has been reported in many countries and estimated that about 150 million people have been exposed to the high concentrations of As (Akinbile and Haque, 2012). The intake of As by humans occurs through drinking water, food and soil and contamination of drinking waters is considered a serious worldwide problem after the acceptable limit of As has been set to $10 \mu \mathrm{g} / \mathrm{L}$ (Pokhrel et al., 2005; USEPA, 2017; WHO, 1993).

Water is one of the important inputs after fertilizer for crop production. When the plants are irrigated with water polluted by various chemicals, it may be dangerous for plants, animals as well as for human being.

High concentrations of As in soil and the use of irrigation water with high As may lead to elevated As concentrations in the agricultural products. If the As contaminated water is used for crop production, As accumulates in the soil and transferred to the plants.

Groundwater contains mainly inorganic forms of As and arsenate form comprises about 50\% of the total As (Abedin et al., 2002). Due to the phosphate and arsenate have similar physicochemical behavior in soils; they compete for the same sorption sites on soil particle surfaces. Addition of phosphate to soil may enhance downward movement of As, leading to increased leaching from the topsoil or increase availability of As in the soil solution resulting in higher uptake by the plants. Arsenate also acts as a phosphate analogue with respect to transport across root plasma membrane with phosphate competing much more effectively for transport sites (Abedin et al., 2002).

Because of the natural and anthropogenic processes, As is present in waters and creates serious environmental problems throughout the world. The biotic and abiotic processes cause As release from the soils to the groundwaters (Corsini et al., 2014). Microorganisms play a key role in the speciation and mobility of As in the environment. In anaerobic environments, a biodiverse group of dissimilatory arsenate reducing bacteria use arsenate $\left(\mathrm{As}^{\mathrm{V}}\right)$ as a terminal electron acceptor and reduce it to arsenite (As ${ }^{\mathrm{III}}$ ) (Sun et al., 2008). The oxidation states of As effect its mobility in groundwaters. While $\mathrm{As}^{\mathrm{V}}$ forms under aerobic conditions, As ${ }^{\mathrm{III}}$ form occurs 
under anaerobic conditions. Due to the $\mathrm{As}^{\mathrm{V}}$ forms has greater affinity to oxyhydroxides and clay minerals, it is less mobile than As ${ }^{\mathrm{III}}$ (Corsini et al., 2014). In all plant species tested so far, it has been shown that arsenate is taken up via the phosphate transport systems (Chatuverdi, 2006).

As concentrations in the edible parts of plants have been reported in crops grown in contaminated soil and irrigated with As contaminated waters (Table 1).

Table 2. Accumulation of As in various plant tissues

\begin{tabular}{|c|c|c|c|c|c|c|c|}
\hline Plants & $\begin{array}{l}\text { Soil As } \\
\text { Conc. } \\
(\mathrm{mg} / \mathrm{kg})\end{array}$ & $\begin{array}{c}\text { As } \\
\text { contaminat } \\
\text { ed } \\
\text { irrigation } \\
\text { waters } \\
(\mathrm{mg} / \mathrm{L})\end{array}$ & $\begin{array}{c}\text { Root } \\
(\mathrm{mg} / \mathrm{kg})\end{array}$ & $\begin{array}{l}\text { Shoot } \\
(\mathrm{mg} / \mathrm{kg})\end{array}$ & $\begin{array}{c}\text { Leaf } \\
(\mathrm{mg} / \mathrm{k} \\
\mathrm{g})\end{array}$ & $\begin{array}{c}\text { Fruit } \\
(\mathrm{mg} / \mathrm{kg}) \\
\text { grain }\end{array}$ & References \\
\hline Rice & $\begin{array}{c}7.31-27 . \\
28\end{array}$ & $0.06-0.72$ & 9.71 & 1.58 & ---- & 0.27 & $\begin{array}{c}\text { (Das et al., } \\
\text { 2004) }\end{array}$ \\
\hline Rice & $\begin{array}{c}2.01-12 . \\
00\end{array}$ & $\begin{array}{c}0.062-0.36 \\
4\end{array}$ & ---- & $\begin{array}{c}0.00-15 . \\
8\end{array}$ & $\begin{array}{l}0.52- \\
3.32\end{array}$ & $\begin{array}{c}0.000-0.09 \\
4\end{array}$ & $\begin{array}{l}\text { (Alam et } \\
\text { al., 2003) }\end{array}$ \\
\hline Rice & & & $8.00-19.20$ & $\begin{array}{c}1.20-4.1 \\
1\end{array}$ & $\begin{array}{l}1.26- \\
3.60\end{array}$ & $0.06-0.33$ & \\
\hline Potato & $6.10-16$. & $0.005-1.01$ & $0.20-0.79$ & $\begin{array}{c}0.08-0.2 \\
4\end{array}$ & $\begin{array}{l}0.05- \\
0.12\end{array}$ & $<0.01$ & (Dahal et \\
\hline $\begin{array}{c}\text { Cauliflow } \\
\text { er }\end{array}$ & 70 & 4 & ---- & ---- & ---- & $1.06-3.45$ & al., 2008) \\
\hline Onion & & & ---- & ---- & 0.55 & 1.02 & \\
\hline Eggplant & & & ---- & ---- & ---- & 0.14 & \\
\hline Tomato & 6230 & $0.50-2.00$ & 2040 & 8.63 & ---- & $<3.00$ & $\begin{array}{l}\text { (Beesley et } \\
\text { al., 2013) }\end{array}$ \\
\hline Tomato & ---- & $1.00-5.00$ & $1.91-3.61$ & $\begin{array}{c}1.16-2.8 \\
3\end{array}$ & ---- & $2.47-4.06$ & $\begin{array}{l}\text { (Burlo et } \\
\text { al., 1999) }\end{array}$ \\
\hline Tomato & ---- & 5.00 & $1.00-20.00$ & \multicolumn{2}{|c|}{$7.00-20.00$} & 2.00 & $\begin{array}{c}\text { (Marmiroli } \\
\text { et al., } \\
\text { 2014) }\end{array}$ \\
\hline Tomato & & & $\begin{array}{c}311.2-149 \\
1.2\end{array}$ & $\begin{array}{c}2.60-14 . \\
70\end{array}$ & $\begin{array}{l}2.70- \\
19.90\end{array}$ & $0.12-0.41$ & $\begin{array}{c}\text { (Carbonell } \\
-\end{array}$ \\
\hline $\begin{array}{l}\text { Bean } \\
\text { plants }\end{array}$ & ---- & $0.00-10.00$ & $\begin{array}{c}30.40-43.1 \\
0\end{array}$ & $\begin{array}{l}14.70- \\
44.30\end{array}$ & $\begin{array}{l}27.20- \\
40.60\end{array}$ & $3.30-4.40$ & $\begin{array}{c}\text { Barrachina } \\
\text { et al., } \\
\text { 1997) }\end{array}$ \\
\hline Tomato & ---- & ---- & ----- & ----- & ---- & $\begin{array}{c}0.0003-0.0 \\
27\end{array}$ & \\
\hline Parsley & ---- & ---- & $\begin{array}{c}0.0037-0.0 \\
30\end{array}$ & 0.0065 & .137 & ---- & $\begin{array}{c}\text { (Bronkows } \\
\text { ka et al. }\end{array}$ \\
\hline Potato & ---- & ---- & ---- & ---- & ---- & $\begin{array}{c}0.0008-0.0 \\
58\end{array}$ & 2008) \\
\hline Wheat & ---- & ---- & ---- & ---- & ---- & $\begin{array}{l}0.025 \\
0.093\end{array}$ & \\
\hline $\begin{array}{l}\text { Bean } \\
\text { plants }\end{array}$ & 7.60 & $1-3$ & $0.18-4.79$ & $\begin{array}{c}0.10-2.6 \\
8\end{array}$ & & $0.05-1.08$ & $\begin{array}{l}\text { (Caporale } \\
\text { et al., } \\
2013)\end{array}$ \\
\hline Lentil & & $0.00-10.00$ & $2-20 \mu \mathrm{g} / \mathrm{g}$ & $\begin{array}{l}0-12 \\
\mu \mathrm{g} / \mathrm{g}\end{array}$ & & & $\begin{array}{l}\text { (Ahmed et } \\
\text { al., 2012) }\end{array}$ \\
\hline
\end{tabular}


Alfalfa (Medicago sativa L.) is used to produce high-quality hay or haylage for dairy and beef cattle and grown as pasture. It is also included in crop rotations to help build nitrogen levels and maintain soil fertility (CBAN, 2013). Alfalfa is a flowering plant in the pea family Fabaceae. It is a cool season perennial legume from three to twelve years depending upon climate and variety. The plants grow to a height of up to 1 metre $(3 \mathrm{ft})$, and have a deep root system sometimes stretching to 4.5 meters $(15 \mathrm{ft})$, which makes it very resilient, especially to droughts, it has a tetraploid genome (Singh et al.. 2009).

Alfalfa is an important crop in diverse farming systems. Alfalfa was grown on almost $33 \%$ of Turkey's cropland and it was approximately $34 \%$ of the total animal green feed crops produced in 2017 (Table 2).

Table 2. Alfalfa Production in Turkey (TSI. 2018)

\begin{tabular}{cccc}
\hline Years & Area Sown (decare) & Green (tonnes) & Hay (tonnes) \\
\hline 2004 & 3200000 & 2300000 & 2000000 \\
2005 & 3750000 & 2100000 & 2400000 \\
2006 & 4440296 & 1814990 & 2820225 \\
2007 & 5348965 & 1697645 & 3513945 \\
2008 & 5557215 & 1843961 & 3907403 \\
2009 & 5692958 & 1747676 & 4037132 \\
2010 & 5688107 & 11676115 & - \\
2011 & 5585525 & 12076159 & - \\
2012 & 6741832 & 11536328 & - \\
2013 & 6286419 & 12616178 & - \\
2014 & 6923055 & 13432968 & - \\
2015 & 6620459 & 13949958 & - \\
2016 & 6501107 & 15714381 & - \\
2017 & 6594319 & 17561190 & \\
\hline
\end{tabular}

Alfalfa is extremely resistant to high levels of contaminants and can be used as a bioaccumulator (Gardea-Torresdey et al., 1999; Gardea-Torresdey et al., 1997; Karimi, 2013; Peralta-Videa et al., 2004). Peralta-Videa et al., (2002) reported that the alfalfa plants are able to accumulate about $26.600 \mathrm{mg} / \mathrm{kg}$ of zinc, $8500 \mathrm{mg} / \mathrm{kg}$ of nickel, $12.000 \mathrm{mg} / \mathrm{kg}$ of copper, $6000 \mathrm{mg} / \mathrm{kg}$ of chromium, and $10.700 \mathrm{mg} / \mathrm{kg}$ of cadmium, individually. Nickel and chromium accumulation in the roots of alfalfa was also reported by Orman (2014). Pajuelo et al. (2008) reported that $25 \%$ of the total number of nodules of alfalfa plants decreases by applying sodium arsenite concentrations ranging from 25 to $35 \mu \mathrm{M}$. Marin et al. (1992) reported that the As form is more important than the As level in solution in determining the phytotoxic effect of As to rice. When As was applied as DMAA form at levels of 0.05 , or $0.2 \mathrm{mg} \mathrm{As} / \mathrm{L}$ an increase in total dry matter was observed as compared to the control (Marin et al., 1992). 
In this study, the alfalfa plants grown by using various concentrations of As-contaminated waters, was evaluated and As accumulation in the shoots of alfalfa plant was investigated. Experimental study is still proceeded, in this period, alfalfa plants were harvested four times, due to analyses of the last two samples were not completed, two harvest data are presented in this study.

\section{Materials and Methods Experimental methodology}

The experimental study was conducted according to completely randomized design factorial with 3 replicates. Ten-kilogram soil samples each air-dried and sieved were placed in the pots after applying basic fertilization (100 mg N/kg, $100 \mathrm{mg} / \mathrm{kg} \mathrm{P,} 100 \mathrm{mg} \mathrm{K} / \mathrm{kg}, 2.5 \mathrm{mg} \mathrm{Fe} / \mathrm{kg}$ ) and also micronutrient mixture (B \% 1.5 w/w, Fe \% 3.0 w/w, Mn \% 3.0 w/w, Zn $\% 4.0 \mathrm{w} / \mathrm{w})$.

Alfalfa seeds were planted in each pot and the plants were grown in greenhouse conditions and the pots were equally watered during the growing period. The alfalfa seeds of $2 \mathrm{~g}$ were planted into each pot. The seeds amount was calculated according to the $3500 \mathrm{~g} / \mathrm{dec}$ are. At harvest, the shoots were collected separately, washed with tap and deionized water to remove impurities, and the fresh weight was determined.

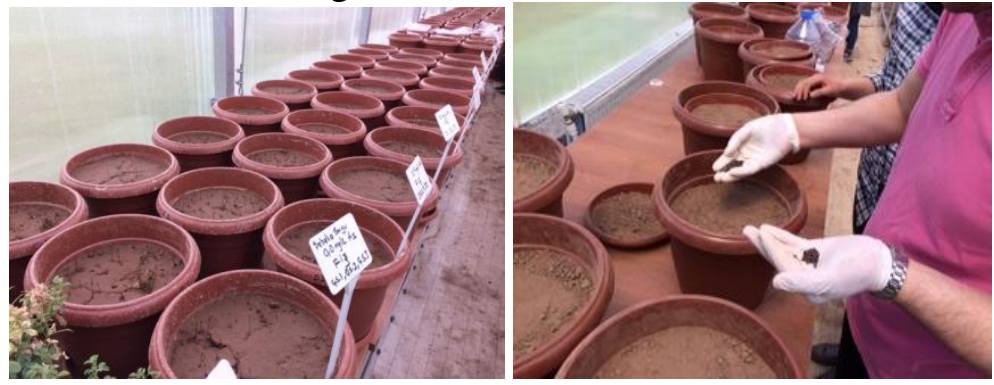

Figure 1. Alfalfa planting

As was supplied as a solution of $\mathrm{NaAsO}_{2}$ in tap water in the concentrations of zero (control pot) 0.5, 1.0, 1.5, 2.0, 2.5, 3.0, 4.0, 6.0, and $8.0 \mathrm{mg} \mathrm{As} / \mathrm{L}$. The irrigation of plants was carried out by weighing the pot before each watering in order to maintain $70 \%$ water holding capacities.

The harvested shoots of alfalfa were separated into aboveground, dried in an oven between $65-75{ }^{\circ} \mathrm{C}$ for about 48 hours, and then dry weight was determined. After the plant samples were ground into powder, they were prepared for analysis. As analysis was carried out by using hydride generation atomic absorption spectrophotometer. 


\section{Results and Discussion}

Experimental study on the As accumulation in the alfalfa plants are ongoing. Because of the alfalfa is a perennial plant, experimental study will be carried out two years in order to evaluate As accumulation in the plant for first and second year. In the first year, alfalfa was planted in the clean soil and irrigated with As contaminated water. During the first year, alfalfa was harvested four times and the analysis of last two harvests and soil samples just have not been carried out. In this study, variations of As accumulation in the shoots and the size of alfalfa irrigated with various As contaminated waters was evaluated. Alfalfa plants grown in greenhouse are presented in Figure 2 .
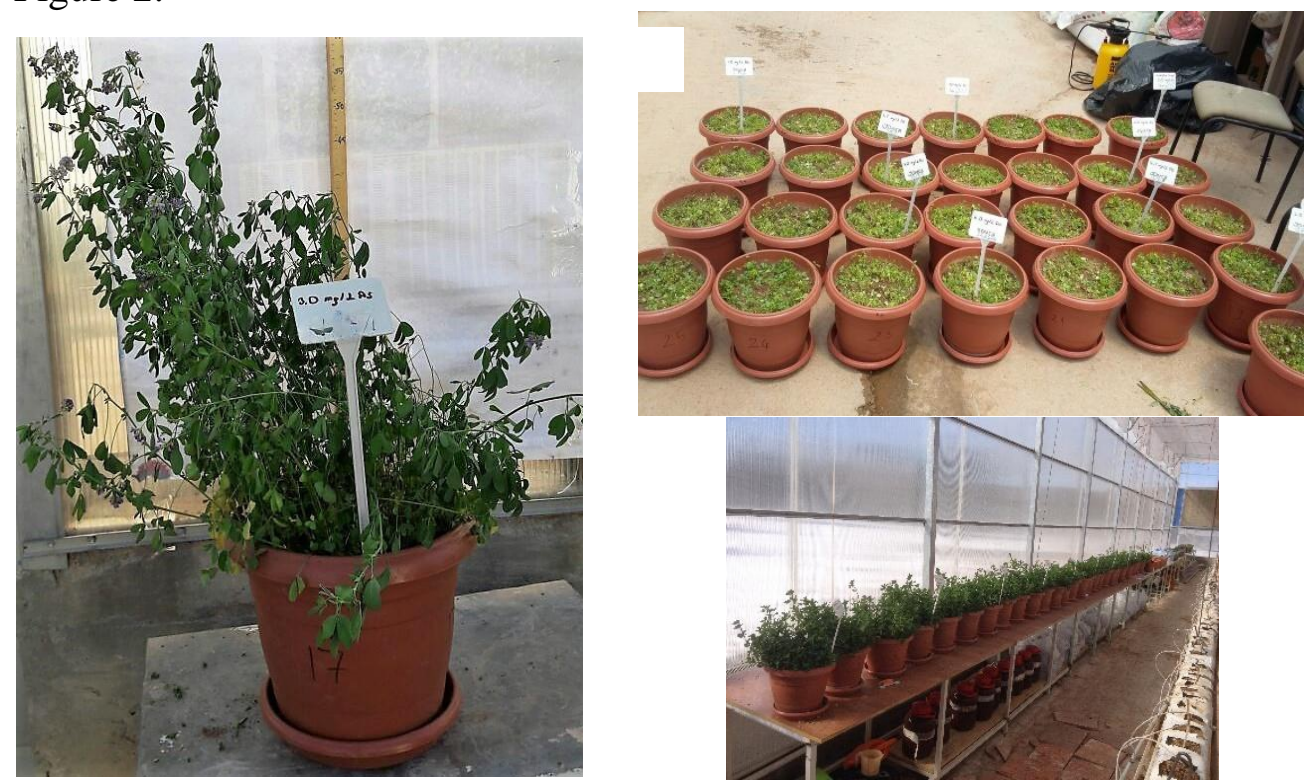

Figure 2. Alfalfa grown in the greenhouse

The data on the heights and numbers of branches at the first harvest is presented in Figure 3. As in irrigation water has a marked effect on the height of alfalfa plant. As can be seen from the figure that significance difference was found in height and numbers of branches growing with control and up to $3 \mathrm{mg}$ As/L. However, differences were not observed for the As concentrations higher than $4 \mathrm{mg} / \mathrm{L}$ with the control unit. It was observed that the plant height slightly increased with increasing As concentrations in irrigation water. Plant height was about $35 \mathrm{~cm}$ for the control units. With the lower range of As doses (0.5-4.0 mg of As/L), plant height ranged between 38 and $45 \mathrm{~cm}$, while with the As doses of $8.0 \mathrm{mg} \mathrm{As} / \mathrm{L}$, plant height decreased to about $35 \mathrm{~cm}$. The number of branches and height of shoots for the As applied pots were higher that the control pots. 
As adding into the irrigation water positively affects the alfalfa growth. About 20\% increase of dry weight was observed for the applied As concentrations up to $4 \mathrm{mg} / \mathrm{L}$ compared to control units and it was slightly decreased by further increase of As concentrations in the irrigation waters (Figure 4). Although As is not considered as an essential plant nutrient, increased dry weight production was observed for tomato (Burlo' et al., 1998; Carbonell-Barrachina, 1995), red clover (Mascher et al., 2002), Spartina alterniflora and Spartina patens (Carbonell-Barrachina et al., 1998), onion (Sushant and Ghosh, 2010), rice (Marin et al., 1992). On the contrary, significant decrease of dry biomass was reported by applying As in some research (Abedin et al., 2002; Carbonell-Barrachina, 1997).

Accumulation of As in the shoots of alfalfa plant presented in Figure 4 was based on the dry weight basis of harvested plant material. The significant increase in level of As in shoots was found with increase in As concentrations in the irrigation waters. When the plant was exposed to 0.5 $\mathrm{mg} \mathrm{As} / \mathrm{L}$, the As concentration was found to be about $1.07 \mathrm{mg} / \mathrm{Kg}$ in shoots. As accumulation in the shoots of alfalfa steadily increased with increase of As concentrations in the irrigation waters. The highest As accumulation of about $12.9 \mathrm{mg} / \mathrm{Kg}$ was observed for the concentration of $8 \mathrm{mg} \mathrm{As} / \mathrm{L}$.

Although significant alfalfa height variations were not observed between controls and As applied pots, numbers of the branches decreased steadily with increase of As concentrations in the irrigation waters at the $2^{\text {nd }}$ harvest (Figure 5). The highest branch numbers were observed for the control pots and its number steadily decreased from 109 to 73 pieces for the control units and $8 \mathrm{mg}$ As/L, respectively.

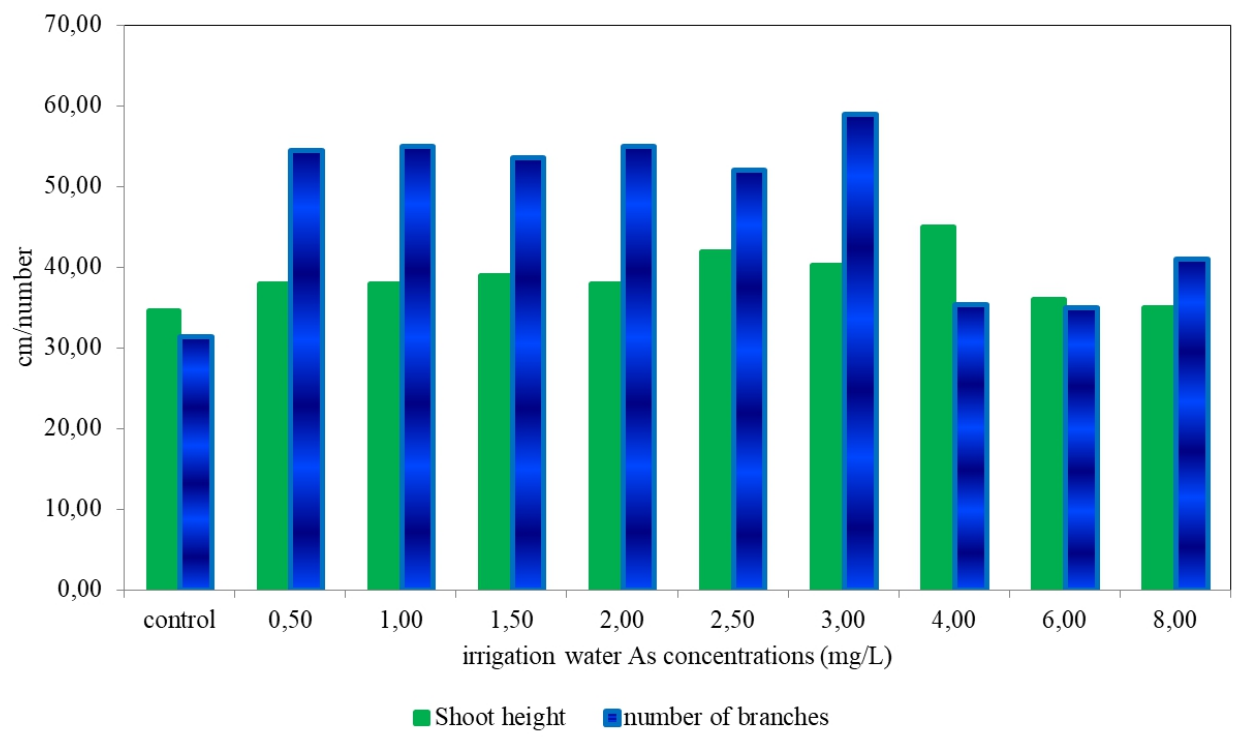

Figure 3. Variations of Alfalfa grown at the $1^{\text {st }}$ harvest. 


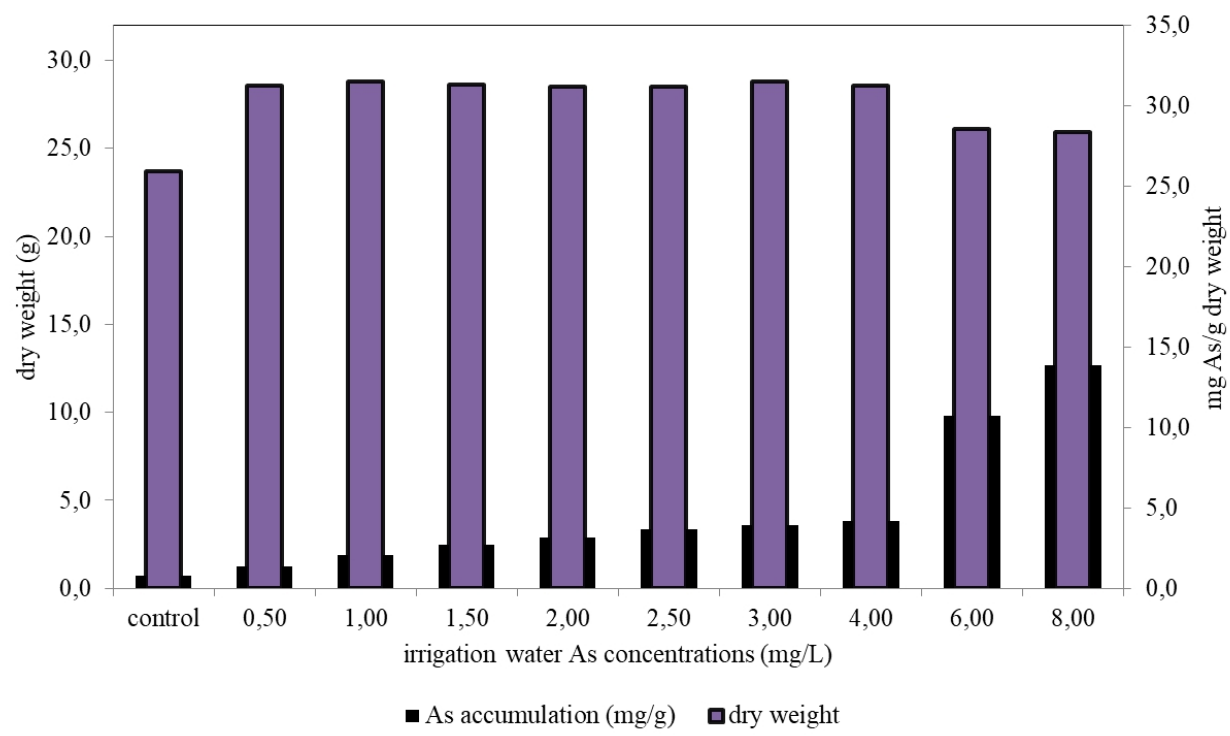

Figure 4. Variations of dry weight and As accumulation in the shoot of alfalfa plant at the $1^{\text {st }}$ harvest.

Variation of shoots dry weight for the $2^{\text {nd }}$ harvest by application of As contaminated waters is presented in Figure 6. Irrigation with As contaminated water resulted in negligible increase of shoot dry weight production than in the control plants. However, biomass production decreased about $11.7 \%$ when the concentration of $8 \mathrm{mg}$ As/L was applied to the pots.

As in the irrigation water is transferred to the soil and accumulated in the root and shoots of plant. During the experimental study, maximum 153 $\mathrm{mg}$ As/pot was applied for the concentration of $8.0 \mathrm{mg} / \mathrm{L}$ up to the $1^{\text {st }}$ harvest and total applied As amount was $208 \mathrm{mg} /$ pot throughout the study. As can be seen from the Figure 7, As accumulation in the shoots of alfalfa plant increased with increasing As concentrations in the irrigation waters. As accumulation in the shoots at the $2^{\text {nd }}$ harvest samples were higher than the $1^{\text {st }}$ samples. However, As accumulation differences between the $1^{\text {st }}$ and $2^{\text {nd }}$ samples decreased when the As concentrations in the irrigation water was higher than $4 \mathrm{mg} / \mathrm{L}$. 


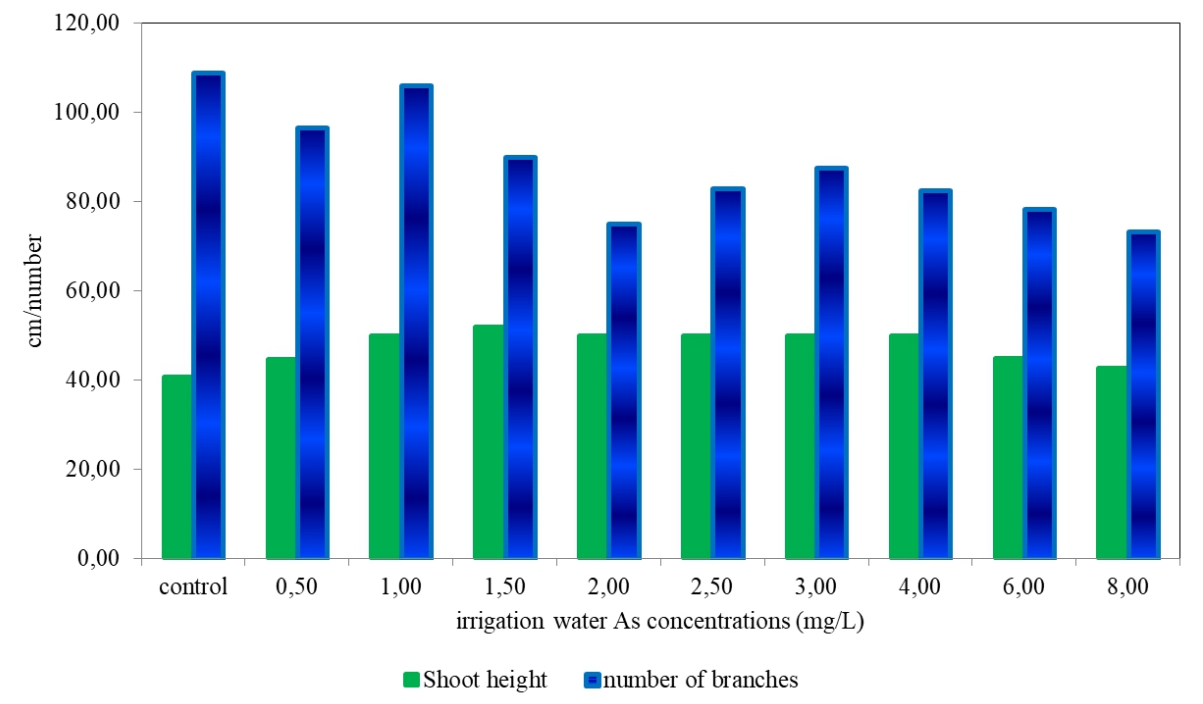

Figure 5. Variations of alfalfa grown at $2^{\text {nd }}$ harvest.

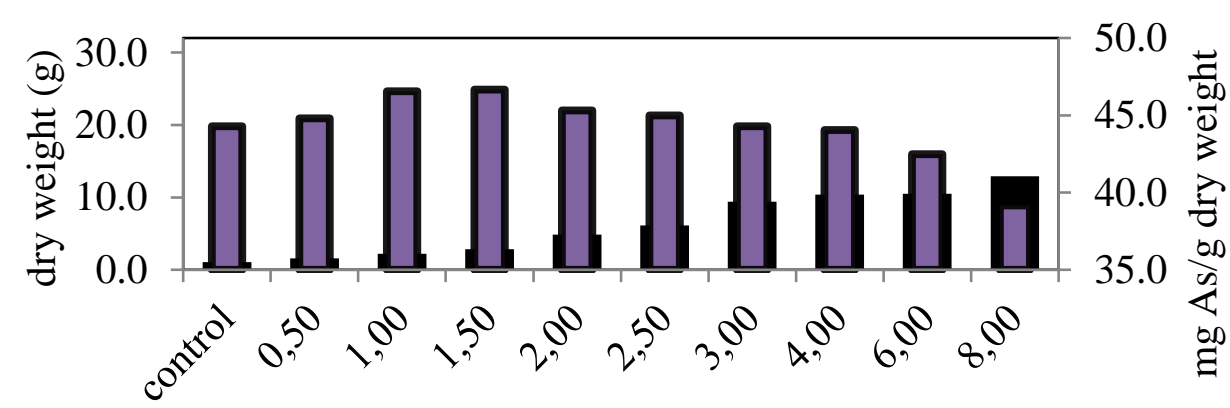
irrigation water As concentrations (mg/L)

- As accumulation (mg/g) Ddry weight

Figure 6. Variations of dry weight and As accumulation in the shoot of alfalfa plant $2^{\text {nd }}$ harvest. 


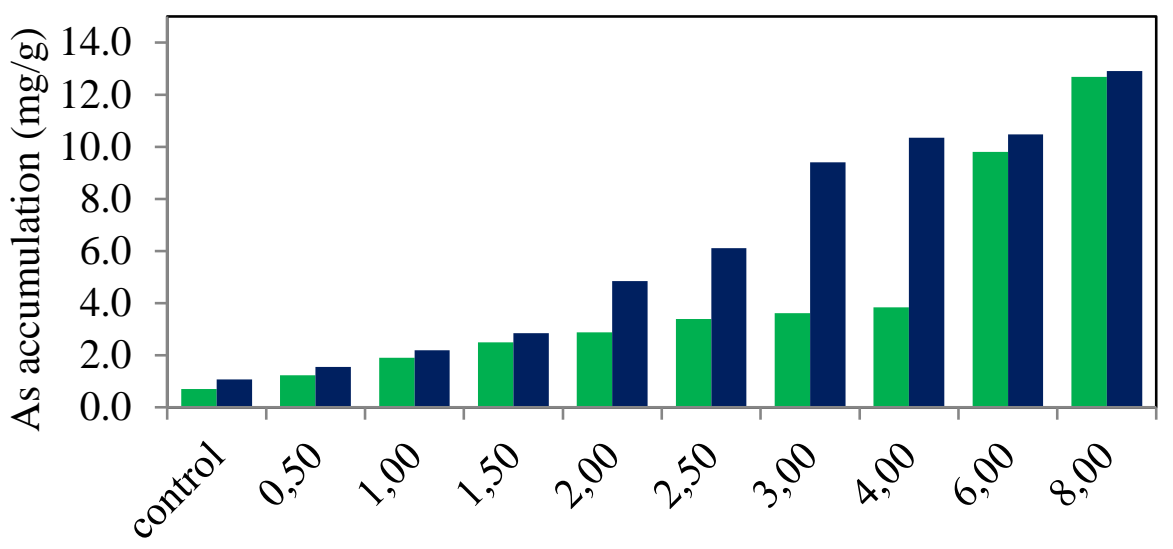

Irrigation water As concentrations $(\mathrm{mg} / \mathrm{L})$

— 1 st harvest $\quad$ 2nd harvest

Figure 7. Comparison of $1^{\text {st }}$ and $2^{\text {nd }}$ harvested for the As accumulation in the shoots.

\section{Conclusion}

As is widely distributed in the environment and it is considered as a toxic metalloid at elevated concentrations. Human and livestock are being exposed to As via As-contaminated drinking water and consumption of food grown in As-contaminated soil or irrigated with As-contaminated water. As is not considered as an essential plant nutrient. However, it was observed that the dry weight of alfalfa increased when the plant was irrigated with As contaminated waters. Similar observations were reported for different plants. As accumulation in the shoots of alfalfa plant increased with increase of As concentration in the irrigation waters. Experimental study is still carried out and roots analysis is not completed yet.

\section{Acknowledgments}

This work was supported by the Scientific and Technical Research Council of Turkey (TUBITAK) under Grant No. 115Y630.

\section{References:}

1. Abedin, M.J., Cresser, M.S., Meharg, A.A., Feldmann, J., and Cotter-Howells, J. (2002). Arsenic Accumulation and Metabolism in Rice (Oryza sativa L.). Environmental Science and Technology. 36. 962-968.

2. Ahmed, F.R.S., Alexander, I.J., Mwinyihija, M., and Killham, K. (2012). Effect of Arsenic Contaminated Irrigation Water on Lens 
Culinaris L. and Toxicity Assessment Using Lux Marked Biosensor, Journal of Environmental Sciences, 24, 6, 1106-1116.

3. Akinbile, C.O. and Haque, A.M.M. (2012). Arsenic Contamination in Irrigation Water for Rice Production in Bangladesh: A Review. Trends in Applied Sciences Research. 7. (5):331-349.

4. Alam, M. Z. and Rahman, M. M. (2003). Accumulation of Arsenic in Rice Plant from Arsenic Contaminated Irrigation Water and Effect on Nutrient Content. In BUET-UNU International symposium of fate of arsenic in the environment, Dhaka, Bangladesh. Conference paper (pp. 131-135).

5. Beesley, L., Marmiroli, M., Pagano, L., Pigoni, V., Fellet, G., Fresno, T., and Marmiroli, N. (2013). Biochar Addition to an Arsenic Contaminated Soil Increases Arsenic Concentrations in the Pore Water but Reduces Uptake to Tomato Plants (Solanum lycopersicum L.), Science of the Total Environment, 454, 598-603.

6. Bronkowska, M., Figurska-Ciura, D., Orzeł, D., Styczyńska, M., Wyka, J., Loźna, K., and Biernat, J. (2008). Evaluation of Plant Products from the Legnicko-Głogowski Region for Their Contamination with Arsenic, Food Chemistry, 109(1), 4-7.

7. Burlo, F., Guijarro, I., Carbonell-Barrachina, A. A., Valero, D., and Martinez-Sanchez, F. (1999). Arsenic Species: Effects on and Accumulation by Tomato Plants. Journal of Agricultural and Food Chemistry, 47(3), 1247-1253.

8. Caporale, A.G., Pigna, M., Sommella, A., Dynes, J.J., Cozzolino, V., and Violante, A. (2013). Influence of Compost on the Mobility of Arsenic in Soil and Its Uptake by Bean Plants (Phaseolus vulgaris L.) Irrigated with Arsenite Contaminated Water, Journal of Environmental Management, 128, 837-843.

9. Carbonell-Barrachina, A.A., Arabi, M.A., DeLaune, R.D., Gambrell, R.P., and Patrick, W.H. (1998). Bioavailability and Uptake of Arsenic by Wetland Vegetation: Effects on Plant Growth and Nutrition, Journal of Environmental Science Health, A33/1, 45/66.

10. CBAN (2013), Canadian Biotechnology Action Network, The Inevitability of Contamination from GM Alfalfa Release in Ontario, https://cban.ca/wp-content/uploads/CBAN-Alfalfa-ContaminationReport-April-2013-Final.pdf.

11. Carbonell-Barrachina, A. A., Burlo, F., Burgos-Hernandez, A., Lopez, E., and Mataix, J. (1997). The Influence of Arsenite Concentration on Arsenic Accumulation in Tomato and Bean Plants. Scientia Horticulturae, 71(3), 167-176. 
12. Chatuverdi, I. (2006). Effects of Arsenic Concentrations and Forms on Growth and Arsenic Uptake and Accumulation by Indian Mustard (Brassica Juncea L.) Genotypes. Journal Central Eropean Agriculture. 7. 1. 31-40.

13. Corsini, A., Zaccheo, P., Muyzer, G., Andreoni, V., and Cavalca, L. (2014). Arsenic Transforming Abilities of Groundwater Bacteria and the Combined use of Aliihoeflea sp. Strain 2WW and Goethite in Metalloid Removal. Journal of Hazardous Materials. 269. 89-97.

14. Dahal, B.M., Fuerhacker, M., Mentler, A., Karki, K.B., Shrestha, R.R., and Blum, W.E.H. (2008). Arsenic Contamination of Soils and Agricultural Plants Through Irrigation Water in Nepal, Environmental Pollution, 155, 157-163.

15. Das, H.K., Mitra, A.K., Sengupta, P.K., Hossain, A., Islam, F., and Rabbani, G.H. (2004). Arsenic Concentrations in Rice, Vegetables, and Fish in Bangladesh: a Preliminary Study, Environment international. 30, 3, 383-387.

16. Gardea-Torresdey, J. L., Tiemann, K. J., Gamez, G., and Dokken, K. (1999). Effects of Chemical Competition for Multi-metal Binding by Medicago sativa (alfalfa), Journal of Hazardous Materials. 69(1). 41-51.

17. Gardea-Torresdey, J.L., Tiemann. K.J., Gonzalez. J.H., and Rodriguez. 0. (1997). Phytofiltration of Hazardous Metal ions by Alfalfa: a Study of Calcium and Magnesium Interferences. Journal of Hazardous Materials, 56, 169-179.

18. Jain, C. K., Ali, I. (2000). Arsenic: Occurrence, Toxicity and Speciation Techniques, Water Research, 34 (17), 4304-4312.

19. Karimi, N. (2013). Comparative Phytoremediation of Chromium-contaminated Soils by Alfalfa (Medicago sativa) and Sorghum Bicolor (L) Moench. International Journal of Scientific Research in Environmental Sciences (IJSRES), 1,3, 44-49.

20. Mascher, R., Lippmann, B., Holzinger, S., and Bergmann, H. (2002). Arsenate Toxicity: Effects on Oxidative Stress Response Molecules and Enzymes in Red Clover Plants, Plant Science, 163, 961-969.

21. Marin, A.R., Masscheleyn, P.H., Patrick, and W.H. Jr. (1992). The Influence of Chemical Form and Concentration of Arsenic in Rice Growth and Tissue Arsenic Concentration. Plant and Soil 139, 175-183.

22. Marmiroli, M., Pigoni, V., Savo-Sardaro, M.L., and Marmiroli, N. (2014). The Effect of Silicon on the Uptake and Translocation of Arsenic in Tomato (Solanum lycopersicum L.), Environmental and Experimental Botany 99 (2014) 9-17 
23. Orman, S., Ok, H., and Kaplan, M. (2014). Application of Sewage Sludge for Growing Alfalfa, its Effects on the Macro-micronutrient Concentration, Heavy Metal Accumulation, and Translocation. Ekoloji. 23. 90. 10-19.

24. Pajuelo, E., Rodriguez-Llorente, I. D., Dary, M., and Palomares, A. J. (2008). Toxic Effects of Arsenic on Sinorhizobiume Medicago sativa Symbiotic Interaction. Environmental Pollution 154. 203-211

25. Peralta-Videa, J. R., Gardea-Torresdey, J. L., Gomez, E., Tiemann, K. J., Parsons, J. G., and Carrillo, G. (2002). Effect of Mixed Cadmium, Copper, Nickel and Zinc at Different pHs upon Alfalfa Growth and Heavy Metal Uptake. Environmental Pollution. 119(3). 291-301.

26. Pokhrel,D., Viraraghavan, T., Asce, F., and Braul, L. (2005). Evaluation of Treatment Systems for the Removal of Arsenic from Groundwater, Practice Periodical of Hazardous, Toxic, and Radioactive Waste Management, ASCE, July, 152-157.

27. Singh A., Eapen S., and Fulekar, and M.H. (2009). Potential of Medicago sativa for uptake of Cadmium from Contaminated Environment. Romanian Biotechnological Letters. 14(1): 4164-4169.

28. Sun. W., Sierra-Alvarez. R., and Field. J.A. (2008). Anoxic Oxidation of Arsenite Linked to Denitrification in Sludges and Sediments. Water Research. 42. (17). 4569-4577.

29. Sushant, K.S., and Ghosh, A.K. (2010). Effect of Arsenic on Photosynthesis, Growth and its Accumulation in the Tissues of Allium cepa (Onion), International Journal of Environmental Engineering and Management, 1, 1, 39-50.

30. TSI (Turkish Statistical Institute) (2017). http://www.tuik.gov.tr.

31. USEPA (2017) https://www.epa.gov/ground-water-and-drinkingwater/national-primary-drinking-water-regulations\#Inorganic.

32. WHO. 1993. Guidelines for Drinking-water Quality. $2^{\text {nd }}$ ed. 1. Recommendations. Geneva. 